\title{
Analysis of Electro-Oxidation Suitability for Landfill Leachate Treatment through an Experimental Study
}

\section{Elena Cristina $\operatorname{Rada}^{1}{ }^{1}$, Irina Aura Istrate ${ }^{1,2}$, Marco $\operatorname{Ragazzi}^{1}$, Gianni Andreottola ${ }^{1}$ and Vincenzo Torretta ${ }^{3}$}

1 Department of Civil, Environmental and Mechanical Engineering, University of Trento, via Mesiano 77, Trento I-38123, Italy; E-Mails: marco.ragazzi@ unitn.it (M.R.); gianni.andreottola@unitn.it (G.A.)

2 Department of Energy Production and Use, University Politehnica of Bucharest, Splaiul Independentei 313, Bucharest 060042, Romania; E-Mail: ia_istrate@yahoo.com

3 Department of Science and High Technology, University of Insubria, Via G.B. Vico 46, Varese I-21100, Italy; E-Mail: vincenzo.torretta@uninsubria.it

* Author to whom correspondence should be addressed; E-Mail: elena.rada@ unitn.it; Tel.: +39-04-6128-2613; Fax: +39-04-6128-2672.

Received: 22 July 2013; in revised form: 9 September 2013 / Accepted: 10 September 2013 / Published: 16 September 2013

\begin{abstract}
This paper examines the efficiency of electro-oxidation used as the single pretreatment of landfill leachate. The experiments were performed on three different types of leachate. The results obtained using this electrochemical method results were analyzed after seven days of treatment. The main characteristics of leachate and a diagram of the experimental apparatus are presented. The overall objectives were to contribute to the knowledge of electrochemical treatments for the reduction of $\mathrm{COD}, \mathrm{BOD}_{5}$, ammonium, and total suspended solids, and also to examine whether there was any resulting hexavalent chromium in the liquid sample. The yields obtained were considered satisfactory, particularly given the simplicity of this technology. Like all processes used to treat refluent water, the applicability of this technique to a specific industrial refluent needs to be supported by feasibility studies to estimate its effectiveness and optimize the project parameters. This could be a future development of the work.
\end{abstract}

Keywords: $\mathrm{BOD}_{5}$; $\mathrm{COD}$; electro-oxidation; landfill leachate 


\section{Introduction}

The leachate generated by municipal solid waste (MSW) landfills contains a high level of organic and inorganic pollutants arising from the biological and physical-chemical processes within the controlled landfills. Leachate treatment is difficult, for a number of reasons [1]:

- High concentrations of organic and inorganic pollutants;

- Variability of the characteristics of the leachate over time, according to the dynamics of the biological degradation of the waste in the landfill (quality fluctuation) and the precipitation and other hydrological balance factors, such as surface runoff, evapotranspiration, field capacity of the landfill, etc. (quantitative fluctuation).

The available treatment alternatives are classified as onsite treatments, which can be grouped as follows:

- Complete treatment i.e., reaching standards for discharging directly into surface waters;

- Pretreatment, i.e., reducing the quantity and/or polluting load of leachate, which is subsequently treated in an off-site plant and/or discharged into the sewage system.

In the last twenty years, several plants have been built to pretreat special refluents in medium-large treatment plants, managing significant quantities of leachate. Very often, these kinds of plants are also designed to treat other types of pollutants from industrial activities or from air washout [2,3]. Generally, after a chemical-physical pretreatment (sifting, chemical precipitation of metals, etc.) and, in some cases, a biological pretreatment (activated sludge, also combined with an ultra-filtration process-Membrane BioReactor, MBR), it is possible to feed the treated leachate into the wastewater line of a municipal plant.

In the case of mature leachates from MSW landfills, the greatest problem in achieving the regulatory levels set for discharging into the sewage system essentially involves the high concentration of ammonium associated with the low biodegradability of the chemical oxygen demand (COD).

In order to tackle this problem, much research has been done over the last ten years to identify innovative solutions for the treatment of liquid waste that contains high concentrations of refractory organic compounds and ammonium. Two types of treatment are of particular interest:

- Chemical electro-oxidation;

- Innovative biological removal.

In addition to the above mentioned solutions, it is also possible to use ammonia stripping plants, in both the gas and vapor phases, or ion exchange resins, to remove the nitrates produced with electro-oxidation or with biological processes, or to use new solutions in chemical-physical treatments [4].

A conventional biological treatment could be adopted, however if biological nitrification/denitrification was applied, the high ammonium content of the leachate would require the addition of an external substrate and this would increase the cost of the treatment.

In the last ten years, for high ammonium concentrations a number of unconventional biological treatments have emerged (SHARON, Single Reactor High activity Ammonia Removal Over Nitrite; ANAMMOX, ANaerobic AMMonium OXidation, and CANON, Completely Autotrophic Nitrogen removal Over Nitrite) [5-9]. These solutions have already been adopted in full-scale plants [10]. 
In particular ANAMMOX (oxidation of ammonium under anaerobic conditions) has been studied since the mid 1990s at the University of Delft [11].

Considering the different alternatives proposed and described in the technical literature [12], taking into consideration the role of electrode materials [13] the priority of this experimental investigation was thus to study the treatability of the leachate using electro-oxidation, because of the simplicity of the plant and its management.

Electrochemical treatments [14-16] consist of applying a voltage that is constant over time (potentiostatic) to the refluent being treated, or alternatively, of passing a current that is constant over time (galvanostatic) through it. The electrolytic cell is the reactor in which this process takes place. As the continuous current flows, the negative electrode (cathode) gives electrons to chemical species, which then diminish; in contrast, the positive electrode (anode) receives electrons from chemical species, which become oxidized. A very important role is role of electrode materials is discussed together with that of other experimental parameters.

Both of these processes encourage the partial or total electrochemical oxidation reactions of the pollutants. Partial conversion is aimed at more easily biodegradable compounds, whilst total conversion is aimed at $\mathrm{CO}_{2}$ and $\mathrm{H}_{2} \mathrm{O}$ as final products. The choice of the electrode materials, voltages, currents and reaction times are decisive factors in the effectiveness of the treatment. Chemical electro-oxidation can be performed in two distinct ways: indirect or direct electro-oxidation [17-19].

An initial form of indirect electro-oxidation takes place in the presence of high concentrations of chlorides, $\mathrm{Cl}^{-}$; first of all, active chlorine is formed on the anode and, in rapid succession, hypochlorite $\mathrm{HClO}$ is produced, which has a strong oxidizing effect. This reaction is particularly suitable for saline refluent leachates. It removes many polluting molecules (for example, ammonium, which is partially transformed into nitrogen gas, $\mathrm{N}_{2}$ ); but there is a risk that organo-chloride sub-products may be formed [17,20-23].

A second type of indirect electro-oxidation leads to the production of hydrogen peroxide $\mathrm{H}_{2} \mathrm{O}_{2}$, which also has a strong oxidizing effect on recalcitrant organic substances. By adding bivalent iron, $\mathrm{Fe}_{2}^{+}$(electro-Fenton), the reaction may be further enhanced [24-26].

Another example of indirect electro-oxidation takes place in the presence of metal ions $\left(\mathrm{Ag}_{2}{ }^{+}, \mathrm{Fe}_{3}{ }^{+}\right.$, $\mathrm{Co}_{3}{ }^{+}, \mathrm{Ni}_{2}{ }^{+}$) in a solution. These ions act as "mediators" and are oxidized onto the anode, passing from a low valence to a higher valence, thereby becoming much more reactive. They thus attack the organic compounds present in the solution and form hydroxyl radicals, which, in turn, are able to oxidize organic compounds. Many studies have demonstrated the efficiency of electrochemical technology in removing various kinds of pollutants [27-31]. Several experiments have been carried out to treat leachate by electro-Fenton. COD removal yields of even more than $85 \%$ were obtained. High yields were also observed for the removal of nitrogen [31-34].

The two main aims of this paper are to:

- Contribute to the knowledge of electrochemical treatments for the reduction of COD, biochemical oxygen demand ( $\left.\mathrm{BOD}_{5}\right)$, ammonium, and total suspended solids in leachate;

- Observe whether there was any hexavalent chromium in the liquid sample due to the different oxidative conditions of this treatment (considering that $\mathrm{Cr}^{\mathrm{III}}$ could be transformed into $\mathrm{Cr}^{\mathrm{VI}}$ by applying electro-oxidation). Differently from $\mathrm{Cr}^{\mathrm{III}}, \mathrm{Cr}^{\mathrm{VI}}$ is a powerful carcinogenic [35], thus its formation must be avoided. 


\section{Materials and Methods}

\subsection{Description of the Landfill}

The landfill studied is located in Piedmont (northern Italy) and consists of three lots. Two lots are full and are in the post-cultivation phase; one lot is currently in use. The cultivation was carried out in lot 1 from 1988 until 1994, and in lot 2, from 1994 until 2000. The landfill receives approximately 25,000 tonnes of MSW per year.

The basin has bottom proofing, which consists of an HDPE sheet and an underlying monitoring layer. Proofing of the various parts of the landfill was carried out using HDPE sheets, with a high adherence, joined with a double layer. Currently the leachate is collected, pumped and stored in tanks and treated out from the landfill plant, in a specific wastewater and liquid waste treatment plant (conventional biological treatment with the third chemical finishing step).

Lots 1 and 2 are currently exhausted.

Lot 3 is wider than the first two, is physically separate from lots 1 and 2, and is basically a separate landfill in terms of storage capacity, leachate, rainwater, and road network. It was dug in three stages (called the 1st, 2nd and 3rd hydraulic sectors), from east to west, and the last stage was completed in 2006. From a management point of view, the most western point (which corresponds to the first stage and part of the second stage) is almost full, and the western part, which began operating following completion of the third stage, is currently being used. The overall area of lot 3 is approximately $30,600 \mathrm{~m}^{2}$.

\subsection{Experimental Apparatus and Sample Characterization}

The experimental apparatus used in the laboratory tests (Figure 1) consisted of:

- A rectangular reactor $(20 \times 10 \times 10 \mathrm{~cm})$, in transparent PVC, with a thickness of $10 \mathrm{~mm}$;

- Two flat square electrodes $(10 \times 10 \mathrm{~cm})$, made from stainless steel [36], which are perforated to allow the electro-osmotic mass to flow through;

- A DC power supply Mitek MICP 3005S (up to $60 \mathrm{~V}$ and up to $5 \mathrm{~A}$ ).

Figure 1. Experimental apparatus used in the tests.

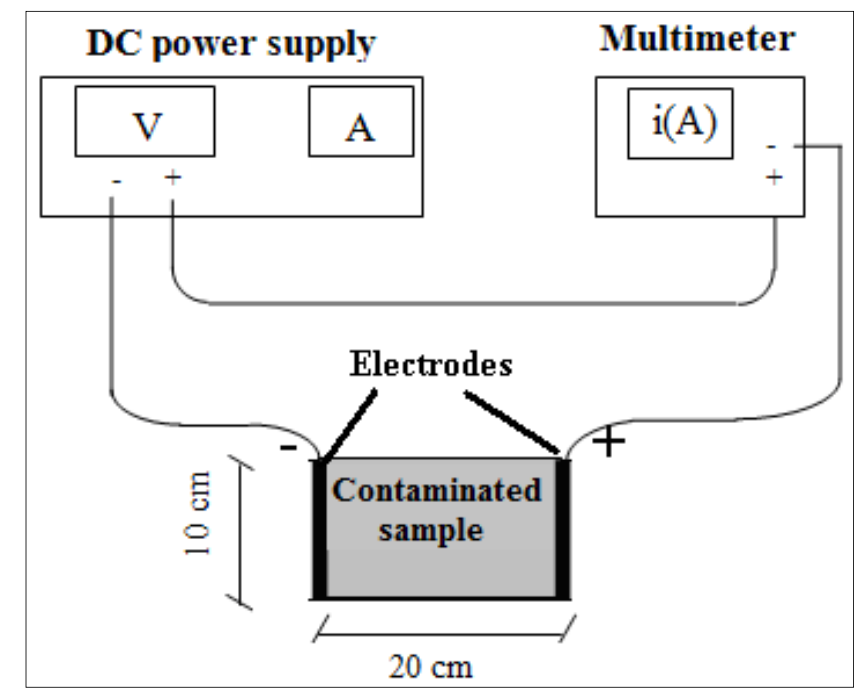


When carrying out the laboratory experiments using this apparatus, the electrodes were inserted into the grooves on the walls of the empty reactor. The empty space between the electrodes was then filled with the contaminated sample. The leachate samples were analyzed in the laboratory. Regarding the intermediary and final sampling, because the sample was liquid, only one mixed sample that characterized the entire sample was taken and then preserved at 4 to $5{ }^{\circ} \mathrm{C}$ or taken directly to the laboratory for analysis.

The methods used for the analyses were MI-127 rev1 2007 (digestion/titration) for COD, MI-128 rev 22007 (respirometric method) for BOD, MI-122 rev 12007 (UV/visible spectro-photometry) for ammonium and hexavalent chromium, UNI EN ISO 14911:2001 for nitrates and nitrites, MI-155 rev 1 2007 (gravimetry) for TSS, and EPA 30522006 + EPA 6010 B 1996 for As, Be, Cd, total Cr, Ni, Pb, $\mathrm{Cu}, \mathrm{Se}$, and $\mathrm{Zn}$.

Table 1 shows the characterization of leachate in the experimental tests. Table 1 highlights that both the Italian regulatory limits for metals and the local sewage company limits were respected, except for copper and zinc. In any case, the main objective of this research did not include the treatment of metals, but rather the assessment of hexavalent chromium concentrations that can potentially change due to different oxidative conditions.

A comparison of data reported in Table 1 with literature data [37-39] demonstrates that the studied leachate is characteristic of an old landfill.

Table 1. Characterization of the leachate.

\begin{tabular}{cccccc}
\hline Parameter & Unit & Lot 1 & Lot 2 & Lot 3 & $\begin{array}{c}\text { Legal limits for } \\
\text { discharge in sewage }\end{array}$ \\
\hline $\mathrm{COD}$ & $\mathrm{mg} \mathrm{O} \cdot \mathrm{L}^{-1}$ & 3,580 & 3,360 & 4,314 & 12,000 \\
$\mathrm{BOD}_{5}$ & $\mathrm{mg} \mathrm{O} \cdot \mathrm{L}^{-1}$ & 420 & 410 & 568 & 250 \\
$\mathrm{BOD}_{5} / \mathrm{COD}$ & - & 0.117 & 0.122 & 0.132 & - \\
Ammonia nitrogen & $\mathrm{mg} \cdot \mathrm{L}^{-1} \mathrm{~N}\left(\mathrm{NH}_{4}\right)$ & $1,728.60$ & $2,181.1$ & $2,296.3$ & 3,500 \\
Nitrite & $\mathrm{mg} \cdot \mathrm{L}^{-1} \mathrm{~N}-\mathrm{NO}_{2}$ & $<0.01$ & $<0.01$ & $<0.01$ & 0.6 \\
Nitrate & $\mathrm{mg} \cdot \mathrm{L}^{-1} \mathrm{~N}_{\mathrm{NO}}$ & 0.10 & 2.64 & 0.16 & 30 \\
Total suspended solids & $\mathrm{mg} \cdot \mathrm{L}^{-1}$ & 542 & 218 & 633 & - \\
Chloride & $\mathrm{mg} \cdot \mathrm{L}^{-1}$ & 871 & 1,563 & 1,304 & 1,200 \\
Arsenic & $\mathrm{mg} \cdot \mathrm{L}^{-1}$ & 0.01 & 0.1 & 0.09 & 0.5 \\
Beryllium & $\mathrm{mg} \cdot \mathrm{L}^{-1}$ & $<0.01$ & $<0.01$ & $<0.01$ & - \\
Cadmium & $\mathrm{mg} \cdot \mathrm{L}^{-1}$ & $<0.002$ & 0.003 & 0.003 & 0.02 \\
Cobalt & $\mathrm{mg} \cdot \mathrm{L}^{-1}$ & 0.03 & 0.07 & 0.07 & - \\
Nickel & $\mathrm{mg} \cdot \mathrm{L}^{-1}$ & 0.41 & 0.64 & 0.70 & 4 \\
Lead & $\mathrm{mg} \cdot \mathrm{L}^{-1}$ & 0.017 & 0.026 & 0.142 & 0.3 \\
Copper & $\mathrm{mg} \cdot \mathrm{L}^{-1}$ & 0.054 & 0.068 & 0.729 & 0.4 \\
Selenium & $\mathrm{mg} \cdot \mathrm{L}^{-1}$ & 0.01 & 0.01 & 0.02 & 0.03 \\
Zinc & $\mathrm{mg} \cdot \mathrm{L}^{-1}$ & 1.12 & 0.54 & 1.37 & 1.0 \\
Total chromium & $\mathrm{mg} \cdot \mathrm{L}^{-1}$ & 0.499 & 0.856 & 1.372 & 4 \\
Hexavalent chromium & $\mathrm{mg} \cdot \mathrm{L}^{-1}$ & $<0.10$ & $<0.10$ & $<0.10$ & 0.2 \\
\hline
\end{tabular}




\subsection{Parameters}

The parameters used in the treatments were adapted in accordance with the behavior of the matrix treated. All samples were characterized by high electrical conductivity values (between $14,500 \mu \mathrm{S} \cdot \mathrm{cm}^{-1}$ and $\left.25,500 \mu \mathrm{S} \cdot \mathrm{cm}^{-1}\right)$. It was therefore necessary to check the specific voltage values $\left(\mathrm{V} \cdot \mathrm{cm}^{-1}\right)$.

In each test, a contaminated sample was introduced into the test cell, and a constant voltage, between 10 and $30 \mathrm{~V}$, was applied for a set period of time (seven days for the first three samples from the three lots of the landfill, and one day for the fourth, made up of perforation water). At the end of each test, the sample was removed from the reactor and analyzed, to determine $\mathrm{COD}, \mathrm{BOD}_{5}$, ammonium, total suspended solid and hexavalent chromium values.

For the first three samples, the specific voltage applied varied between $1.5 \mathrm{~V} \cdot \mathrm{cm}^{-1}$ and $0.5 \mathrm{~V} \cdot \mathrm{cm}^{-1}$. During the first hour of treatment, the specific voltage was set at $1.5 \mathrm{~V} \cdot \mathrm{cm}^{-1}$, but the recorded current was too high (between $2 \mathrm{~A}$ and $3 \mathrm{~A}$ ). In the next hour, the specific voltage was reduced to $1 \mathrm{~V} \cdot \mathrm{cm}^{-1}$. In the end, it was decided that the specific voltage used should be $0.5 \mathrm{~V} \cdot \mathrm{cm}^{-1}$.

The treatment period was seven days, with intermediate liquid samples and sludge taken after the first three days. In the literature, a maximum period of treatment is measured in hours $(3-6 \mathrm{~h})$ and not in days (as in this research), but the idea was to observe the behavior of the electrochemical treatment when no chemical substances were used.

We divided the treatment into two phases:

- Phase 1: lasting 3 days, application of a specific voltage of $0.5 \mathrm{~V} \cdot \mathrm{cm}^{-1}$;

- Phase 2: until the end of the test, with the application of a specific voltage of $1 \mathrm{~V} \cdot \mathrm{cm}^{-1}$.

The idea of two phases with two different specific voltages was due to the fact that at the beginning of the test, the current value was too high and the power supply was not able to sustain a high voltage that would have corresponded to a specific voltage of $1 \mathrm{~V} \cdot \mathrm{cm}^{-1}$. After three days, the current value dropped and the specific value of $1 \mathrm{~V} \cdot \mathrm{cm}^{-1}$ was established.

For the last sample, the treatment was applied only for one day, with a specific voltage of $1 \mathrm{~V} \cdot \mathrm{cm}^{-1}$.

\section{Results and Discussion}

The parameters monitored during the tests were: current, initial and final $\mathrm{pH}$, initial and final electrical conductivity, and specific voltage. Table 2 shows the main characteristics of the tests carried out. In some cases, there was a peak in the current (which was occasionally very marked) in the initial moments of the test, followed by a gradual decrease. In all the tests, the current fell until it reached a level that remained constant for the remainder of the test, and then settled at very low values.

Table 2. Summary of the lab tests carried out during the experiments.

\begin{tabular}{ccccc}
\hline Test & Applied voltage (V) & $\begin{array}{c}\text { Specific voltage } \\
\left(\mathbf{V} \cdot \mathbf{c m}^{-\mathbf{1}}\right)\end{array}$ & Duration (day) & Peak current (mA) \\
\hline Lot 1 & $10 \div 20$ & $0.5 \div 1$ & 7 & 1,480 \\
Lot 2 & $10 \div 20$ & $0.5 \div 1$ & 7 & 1,760 \\
Lot 3 & $10 \div 20$ & $0.5 \div 1$ & 7 & 1,050 \\
\hline
\end{tabular}


The current densities recorded were approximately $5.2 \div 8.8 \mathrm{~mA} \cdot \mathrm{cm}^{-2}$ (the surface of the electrochemical cell was about $200 \mathrm{~cm}^{2}$ and the current had a variation between $1.04 \mathrm{~A}-1.76 \mathrm{~A}$ ) at the beginning of the test, and fell significantly over time. These results differ slightly from the values reported in the literature [40] for electrochemical processes $\left(1 \mathrm{~mA} \cdot \mathrm{cm}^{-2}\right)$.

\subsection{Lot 1 Test}

This test was carried out for a treatment period of seven days, with a specific voltage that varied from 0.5 to $1 \mathrm{~V} \cdot \mathrm{cm}^{-1}$.

During the initial hours of treatment, it was decided that a voltage of $1.5 \mathrm{~V} \cdot \mathrm{cm}^{-1}$ should be applied, however, given that, already after the first 30 minutes, the current value was greater than $2.8 \mathrm{~A}$, the voltage was eventually reduced to $0.5 \mathrm{~V} \cdot \mathrm{cm}^{-1}$. This voltage was kept constant for the first three days of treatment, after which, it was increased to $1 \mathrm{~V} \cdot \mathrm{cm}^{-1}$ in the second part of the treatment, because the current tended to fall to a constant value, which, in the case in question, did not exceed $170 \mathrm{~mA}$. The values recorded during monitoring are shown in Table 3.

Table 3. Trend of the electrical current (test lot 1).

\begin{tabular}{ccc}
\hline Time (h) & Current $(\mathbf{A})$ & Specific voltage $\left(\mathbf{V} \cdot \mathbf{c m}^{\mathbf{- 1}}\right)$ \\
\hline 0.25 & 1.48 & 1 \\
0.5 & 0.689 & 0.5 \\
21 & 0.324 & 0.5 \\
48 & 0.235 & 0.5 \\
72 & 0.166 & 0.5 \\
72.9 & 0.289 & 1 \\
144 & 0.478 & 1 \\
168 & 0.115 & 1 \\
\hline
\end{tabular}

Taking into account the current values measured, the energy consumed was also assessed, and was found to be $740 \mathrm{kWh} \cdot \mathrm{m}^{-3}\left(0.74 \mathrm{kWh} \cdot \mathrm{L}^{-1}\right)$.

By the end of the treatment, the $\mathrm{pH}$ increased slightly from its initial value of 7.5 to 7.7. The electrical conductivity fell from an initial value of $18.87 \mathrm{mS} \cdot \mathrm{cm}^{-1}$, to $13.04 \mathrm{mS} \cdot \mathrm{cm}^{-1}$, after seven days of treatment.

Table 4 shows the characterization of the sample, before, during and after the treatment.

Table 4. Results of the Lot 1 sample treatment.

\begin{tabular}{ccccc}
\hline Parameter & Unit of measurement & Initial & Final & Treatment efficiency (\%) \\
\hline COD & $\mathrm{mg} \mathrm{O}{ }_{2} \cdot \mathrm{L}^{-1}$ & 3,580 & 1,062 & 70.34 \\
BOD & $\mathrm{mg} \mathrm{O} \mathrm{L}_{2} \cdot \mathrm{L}^{-1}$ & 420 & 133 & 68.33 \\
Ammonia nitrogen & $\mathrm{mg} \mathrm{N}\left(\mathrm{NH}_{4}\right) \cdot \mathrm{L}^{-1}$ & $1,728.6$ & $1,066.2$ & 38.32 \\
Nitrite & $\mathrm{mg} \mathrm{N}-\mathrm{NO}_{2} \cdot \mathrm{L}^{-1}$ & $<0.01$ & $<0.01$ & - \\
Nitrate & $\mathrm{mg} \mathrm{N}-\mathrm{NO}_{3} \cdot \mathrm{L}^{-1}$ & 0.1 & 611.79 & $-^{\mathrm{a}}$ \\
Total suspended solids & $\mathrm{mg} \cdot \mathrm{L}^{-1}$ & 542 & 74 & 86.35 \\
Hexavalent chromium & $\mathrm{mg} \cdot \mathrm{L}^{-1}$ & $<0.1$ & $<0.1$ & - \\
\hline
\end{tabular}

${ }^{a}$ The higher quantity of nitrate after the treatment was due to ammonia nitrogen transformation. 
Italian regulations for discharging into a sewage system establish require a maximum value for $271 \mathrm{COD}$ of $500 \mathrm{mg} \cdot \mathrm{L}^{-1}$ for COD. For the sample to conform with this, it is was necessary to apply the treatment for a time significantly longer than the seven days already tested, given that it was demonstrated that the electrochemical treatment is was more effective with longer treatment times, but has not a linear kinetics [41].

After the first three days, sedimentation was observed, which had a volume of $0.3 \mathrm{~L}$ for lot 1 .

From Table 4 it can be clearly observed that the efficiency of ammonium removal was low, the remaining ammonium concentration was about $1,000 \mathrm{mg} \cdot \mathrm{L}^{-1}$. The portion finally removed was $38.32 \%$. The ammonium removed appeared to have been almost entirely transformed into nitrate.

An amount of $86.35 \%$ of total suspended solids had been removed from the liquid after the 7 -day treatment.

\subsection{Lot 2 Test}

This treatment lasted for seven days, with a specific voltage that varied between 0.5 and $1 \mathrm{~V} \cdot \mathrm{cm}^{-1}$. The same treatment strategy described for the Lot 1 test was used. The trend of the current monitored during the test is shown in Table 5. The amount of energy consumed was $377 \mathrm{kWh} \cdot \mathrm{m}^{-3}\left(0.38 \mathrm{kWh} \cdot \mathrm{L}^{-1}\right)$.

Table 5. Trend of the electrical current (Lot 2 test).

\begin{tabular}{ccc}
\hline Time (h) & Current (A) & Specific voltage $\left(\mathbf{V} \cdot \mathbf{c m}^{-\mathbf{1}}\right)$ \\
\hline 0.17 & 1.76 & 1 \\
0.5 & 0.763 & 0.5 \\
21 & 0.27 & 0.5 \\
48 & 0.097 & 0.5 \\
72 & 0.069 & 0.5 \\
72.25 & 0.658 & 1 \\
144 & 0.083 & 1 \\
168 & 0.072 & 1 \\
\hline
\end{tabular}

The $\mathrm{pH}$ value increased slightly by the end of the treatment: from its initial value of 7.5 to a final value of 7.7. The electrical conductivity fell from the initial value of $25.4 \mathrm{mS} \cdot \mathrm{cm}^{-1}$, to $17.21 \mathrm{mS} \cdot \mathrm{cm}^{-1}$ (after seven days of treatment).

The characterization of the sample, before, during and after the treatment is shown in Table 6.

Table 6. Results of the Lot 2 sample treatment.

\begin{tabular}{ccccc}
\hline Parameter & Unit & Initial & Final & Treatment efficiency (\%) \\
\hline COD & $\mathrm{mg} \mathrm{O}_{2} \cdot \mathrm{L}^{-1}$ & 3,360 & 1,176 & 65.00 \\
BOD & $\mathrm{mg} \mathrm{O}_{2} \cdot \mathrm{L}^{-1}$ & 410 & 150 & 63.41 \\
Ammonia nitrogen & $\mathrm{mg} \mathrm{N}\left(\mathrm{NH}_{4}\right) \cdot \mathrm{L}^{-1}$ & $2,181.1$ & $1,851.9$ & 15.09 \\
Nitrite & $\mathrm{mg} \mathrm{N}-\mathrm{NO}_{2} \cdot \mathrm{L}^{-1}$ & $<0.01$ & $<0.01$ & - \\
Nitrate & $\mathrm{mg} \mathrm{N}-\mathrm{NO}_{3} \cdot \mathrm{L}^{-1}$ & 2.64 & 209.64 & $-^{\mathrm{a}}$ \\
Total suspended solids & $\mathrm{mg} \cdot \mathrm{L}^{-1}$ & 218 & 246 & $-^{\mathrm{b}}$ \\
Hexavalent chromium & $\mathrm{mg} \cdot \mathrm{L}^{-1}$ & $<0.1$ & $<0.1$ & - \\
\hline
\end{tabular}

${ }^{a}$ The higher quantity of nitrate after the treatment is due to ammonia nitrogen transformation; ${ }^{\mathrm{b}}$ The increase in TSS is due to the electrode corrosion. 
A modest removal of COD and BOD was observed after the first three days of treatment, which continued to improve by the end of the treatment (from $25 \%$ to $65 \%$ for COD, and from $30 \%$ to $64 \%$ for BOD).

In view of the national maximum value $\left(\mathrm{COD}=500 \mathrm{mg} \cdot \mathrm{L}^{-1}\right)$ for discharging into the sewage system, the treatment was continued at least another 14 days (in addition to the seven already tested).

After the first three days, sedimentation could be seen, which, for lot 2, had a volume of $0.35 \mathrm{~L}$.

For ammonium there was a modest final removal, of only $15.09 \%$. In addition, in this case, ammonium seemed to be transformed into nitrate, for which an increase was recorded.

In this case, the total suspended solids did not register any removal, but an increase by nearly $13 \%$ after the 7-day treatment. This was due, in part, to the corrosion of the steel plates, with a subsequent release of suspended matter, and, in part, to electro-flocculation following the release of iron ions into the solution.

\subsection{Lot 3 Test}

Similar methods were used for the test for Lot 3 (duration 7 days, voltage $0.5-1 \mathrm{~V} \cdot \mathrm{cm}^{-1}$ ) (Table 7). The energy consumed amounted to $689 \mathrm{kWh} \cdot \mathrm{m}^{-3}\left(0.689 \mathrm{kWh} \cdot \mathrm{L}^{-1}\right)$.

Table 7. Trend of the electrical current (Lot 3 test).

\begin{tabular}{ccc}
\hline Time (h) & Current(A) & Specific voltage $\left(\mathbf{V} \cdot \mathbf{c m}^{\mathbf{- 1}}\right)$ \\
\hline 0.09 & 1.05 & 1 \\
0.5 & 0.337 & 0.5 \\
21 & 0.361 & 0.5 \\
48 & 0.194 & 0.5 \\
72 & 0.094 & 0.5 \\
72.5 & 0.563 & 1 \\
144 & 0.629 & 1 \\
168 & 0.607 & 1 \\
\hline
\end{tabular}

A comparison of the current values for all three samples (Figure 2), reveals that even though the maximum value for the Lot 3 experiment was the lowest, the steady state value was the highest. In addition, for Lot 3 the last three measured values were very similar compared with the same values as in the Lot 1 and Lot 2 tests, where the variation is more obvious.

By the end of the treatment, $\mathrm{pH}$ increased slightly from its initial value of 7.5, to 8.1. In contrast, the electrical conductivity decreased from $26.7 \mathrm{mS} \cdot \mathrm{cm}^{-1}$ to $19 \mathrm{mS} \cdot \mathrm{cm}^{-1}$ (after seven days of treatment) (Table 8).

Table 8. Results of the Lot 3 sample treatment.

\begin{tabular}{ccccc}
\hline Parameter & Units of measurement & Initial & Final & Treatment efficiency (\%) \\
\hline COD & $\mathrm{mgO}_{2} \cdot \mathrm{L}^{-1}$ & 4,314 & 1,506 & 65.09 \\
BOD & $\mathrm{mgO}_{2} \cdot \mathrm{L}^{-1}$ & 568 & 197 & 65.32 \\
Ammonia nitrogen & $\mathrm{mgN}\left(\mathrm{NH}_{4}\right) \cdot \mathrm{L}^{-1}$ & $2,296.3$ & 902.1 & 60.72 \\
Nitrite & $\mathrm{mgN}-\mathrm{NO}_{2} \cdot \mathrm{L}^{-1}$ & $<0.01$ & $<0.01$ & - \\
Nitrate & $\mathrm{mgN}-\mathrm{NO}_{3} \cdot \mathrm{L}^{-1}$ & 0.16 & 993.29 & $-^{\mathrm{a}}$ \\
Total suspended solids & $\mathrm{mg} \cdot \mathrm{L}^{-1}$ & 633 & 383.6 & 39.40 \\
Hexavalent chromium & $\mathrm{mg} \cdot \mathrm{L}^{-1}$ & $<0.1$ & $<0.1$ & - \\
\hline
\end{tabular}

${ }^{\mathrm{a}}$ The higher quantity of nitrate after the treatment is due to ammonia nitrogen transformation. 
Figure 2. Comparison between current values for Lots 1, 2 and 3.

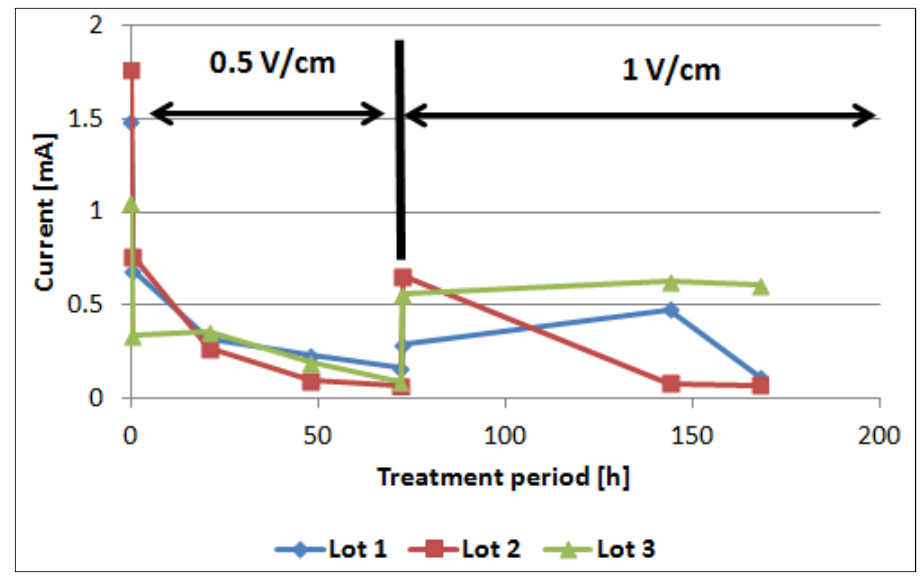

Here, too, in view of the limits regarding discharging into the sewage system, the treatment was continued for at least another 14 days (in addition to the seven already tested) to allow the sample to conform.

After the first three days, sedimentation was seen, with a volume of $0.35 \mathrm{~L}$.

The final amount of ammonium removed was $60.72 \%$. Here, too, it appeared to have transformed, in part, into nitrate, which registered an increase.

In this case, the total suspended solids registered a removal of almost 39.4\% after the 7-day treatment. This increase could be attributed to corrosion of the steel electrodes, which may also occur in laboratory electro-oxidation tests carried out with steel plates. In real-scale plants, probes made of titanium activated with noble metals, are used, which are entirely free of corrosion. The increase in the suspended solids was also due also to electro-flocculation, caused after iron ions were released into the solution.

\subsection{Results of the Leachate Samples}

Figure 3 compares the initial and final characterizations, for the three treated leachate samples.

Figure 3. Comparison between the initial concentrations and the treatment results for the three leachate samples.

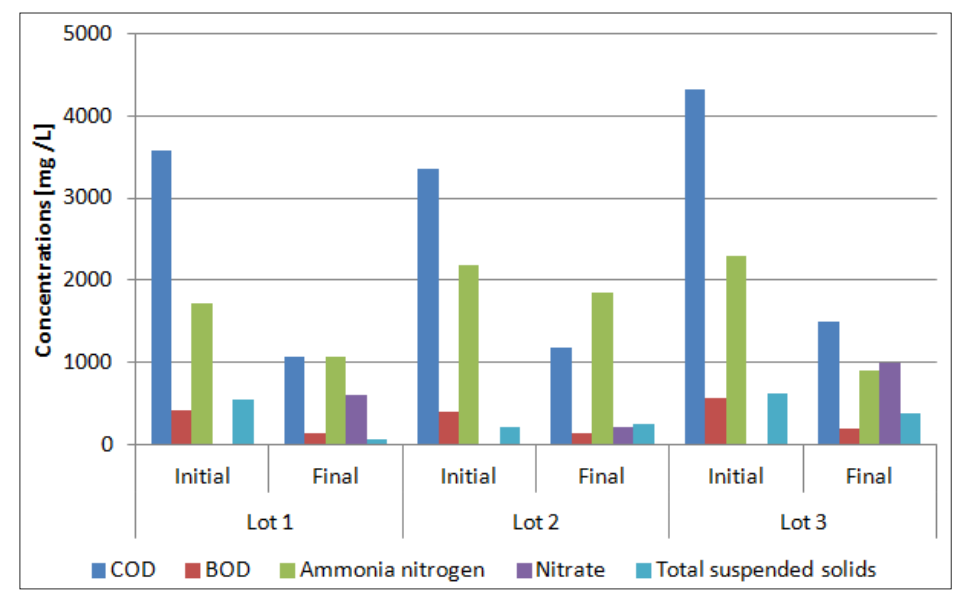

Figures 4 and 5 compare the discharge limits set by Italian regulations (Leg. Dec. No. 152/2006) [42] with the samples before and after the 7-day treatment, respectively. 
Figure 4. Initial concentrations of three leachate samples compared with regulation limits.

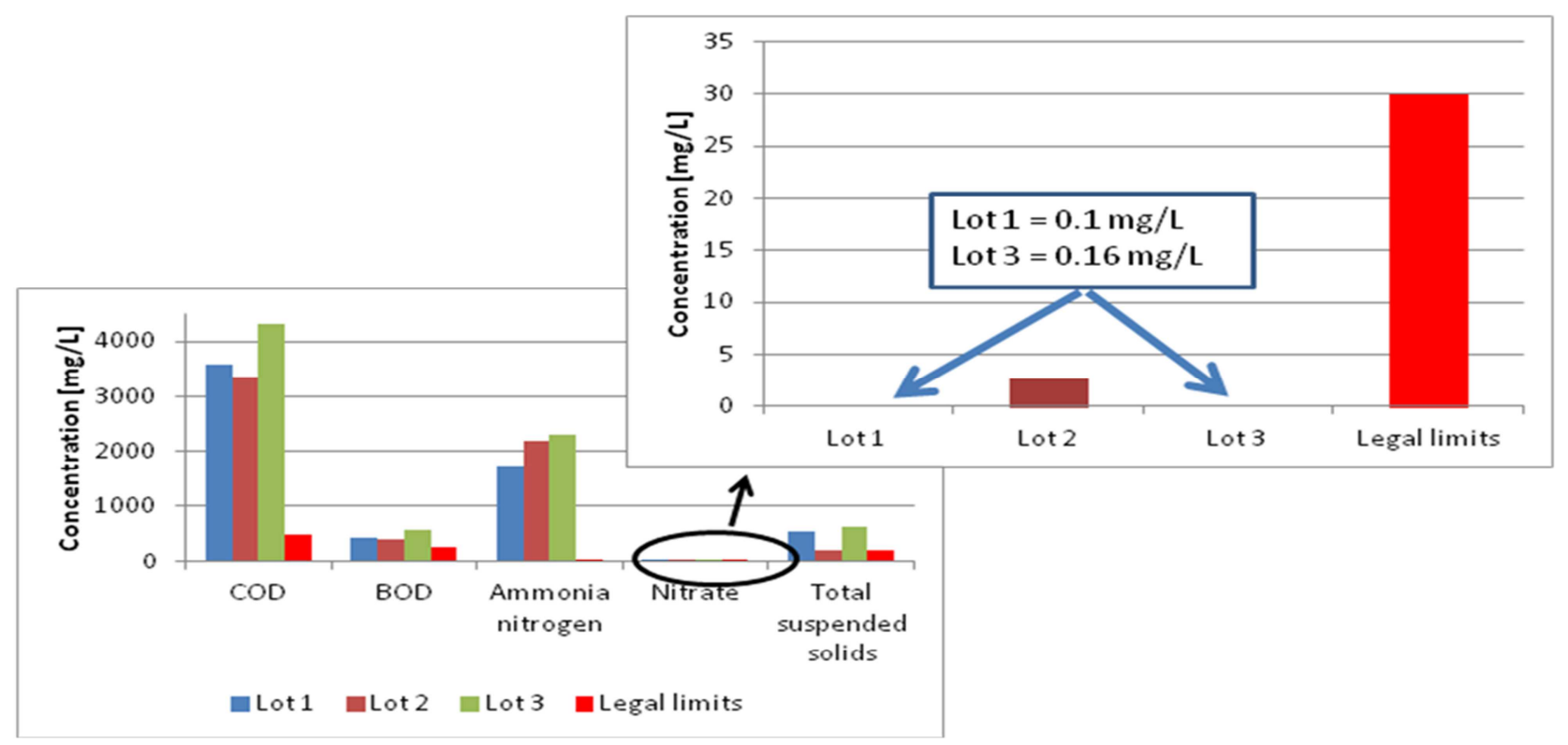

Figure 5. Final concentrations of the three leachate samples and comparison with the regulation limits.

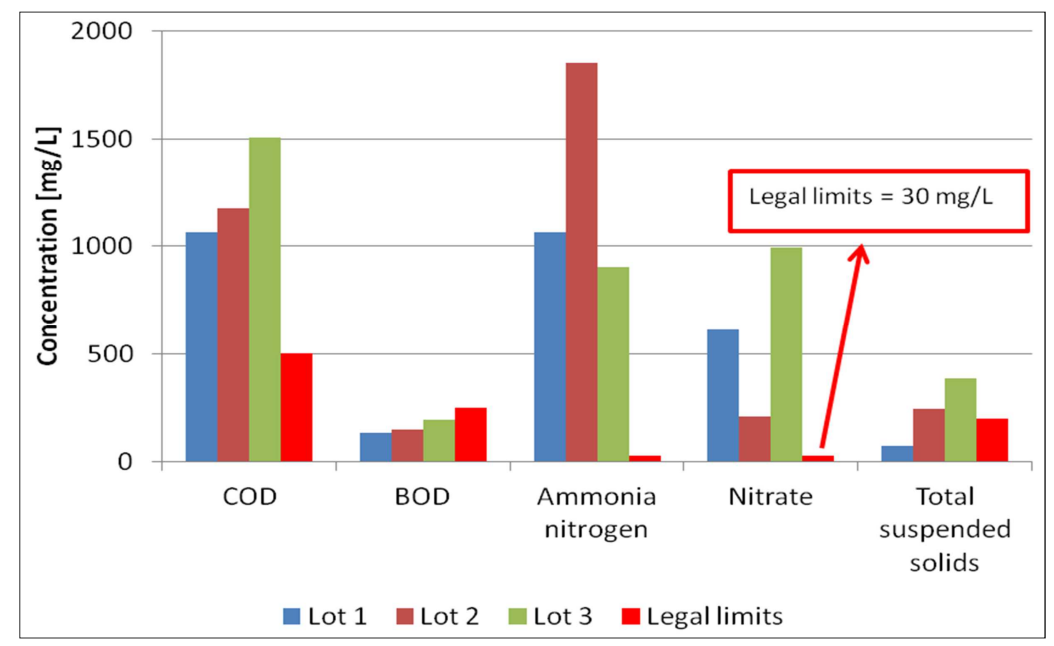

In none of the cases were the limits established for COD, ammonium and nitrate complied with. Furthermore, for the samples from Lots 2 and 3, the limits established for total suspended solids, total chromium, nickel and copper were not complied with, because of the mechanisms described above, which are only important on a laboratory scale, when stainless steel electrodes are used.

Sedimentation in all three treatment (Lot 1, Lot 2 and Lot 3) samples was observed which may be due to the electrode corrosion.

Another important aspect is that the rate of ammonia converted into nitrate resulted variable: $35 \%$ for Lot 1, 10\% for Lot 2 and $43 \%$ for Lot 3.

Moreover, data of $\mathrm{Cr}^{\mathrm{VI}}$ in Tables 4, 6 and 8 demonstrate that there is no detectable conversion of $\mathrm{Cr}^{\mathrm{III}}$ into $\mathrm{Cr}^{\mathrm{VI}}$, with a clear advantage compared to other phenomena involving these forms of $\mathrm{Cr}$ (i.e., combustion [43], soils with specific composition [44]). 
Very high values of power consumption were found, about ten times higher than previously reported data [41]. This is a demonstration that electro-oxidation is very sensible to the materials adopted at the electrodes.

\section{Conclusions}

Problems related to landfills are of great importance, considering both the real environmental pressure, with particular focus on leachate production, and the social acceptation of the risks for human health [45]. Thus, focusing research on leachate management and treatment is extremely important. We thus carried out tests on a laboratory scale, on a number of samples of landfill leachate, in order to verify the efficiency of electro-oxidation in terms of treatment.

The yields obtained are satisfactory, particularly considering the simplicity of the technology. As with all processes for treating wastewater, the applicability of this technique to a specific industrial effluent needs to be supported by feasibility studies that estimate its effectiveness and optimize the design parameters.

Electrochemical oxidation easily removed $64 \%-70 \%$ of COD, and 15\%-61\% of ammonium. The intervention was helped by the electrical conductivity, which had a fairly high value. In order to achieve the discharging limits for COD, and particularly those for nitrogen, electro-oxidation alone is not sufficient, and other treatments are needed.

Energy consumption for electro-oxidation treatment varied between 0.377 and $0.740 \mathrm{kWh} \cdot \mathrm{L}^{-1}$, depending on the treated sample. These values are only indicative, as they relate to laboratory tests, in which the optimal choice of electrode materials and of reaction times has not yet been obtained. In the literature, results related to energy consumption vary between $0.012 \mathrm{kWh} \cdot \mathrm{L}^{-1}$ and $0.039 \mathrm{kWh} \cdot \mathrm{L}^{-1}$ [46]. The selection of the anodic material based on cost limitation demonstrated that the energy consumption can increase significantly.

During the first few days of treatment, sedimentation of the samples was observed, which was usually equal to a third of the initial sample volume.

One problem was the presence of a higher value for some metals at the end of the treatment than at the beginning, , which may have been due the corrosion of the electrodes.

In light of the tests carried out, electro-oxidation technology could be applied to leachates, to reduce the concentration of refractory organic matter and ammonium.

However, using this technology alone it appears that it is not possible to achieve the limits for discharging into sewerage, except where local limits for carbonaceous substances and nitrogen are decidedly more permissive.

Although a high energy consumption and a potential chlorinated organic formation may limit its application, electrochemical oxidation is a promising and powerful technology for the treatment of landfill leachate as was also stated by Deng and Englehardt in 2007 [26]. In general, it is reasonable to consider that electro-oxidation makes sense when renewable energy is used. This has recently been highlighted by several authors [47-50].

For the treatment of leachate, the most interesting solution might be to apply electro-oxidation in combination with hydrogen peroxide (electro-Fenton), when the main objective is to reduce the COD concentration under the discharging limits. However, when the intention is also to significantly reduce nitrogen, the easier alternative from a management point of view is to apply ammonia stripping in a 
washing tower, by $\mathrm{pH}$ conditioning. Alternatively, we suggest applying innovative, biological processes (ANAMMOX), which, despite limited application on a real scale internationally, are able to achieve around $80 \%$ nitrogen abatement.

Another limit to integrating electrochemical processes with ANNAMOX involves a negligible formation of nitrites.

In conclusion, the process sequence might be:

- Sequence 1: ammonia stripping + electro-oxidation (or electro-Fenton);

- Sequence 2: ANAMMOX, with an anaerobic membrane reactor, followed (if necessary) by electro-oxidation (or electro-Fenton).In this paper only initial and final values of the parameters characterizing the contaminant load are given; however, the process should be analyzed also on a kinetic basis and this is the natural development of the work. In fact a specific kinetic study is actually in project, after a feasibility study to verify in details the viability of the proposed hybrid treatment.

\section{Conflicts of Interest}

The authors declare no conflict of interest.

\section{References}

1. Pi, K.W.; Li, Z.; Wan, D.J.; Gao, L.X. Pretreatment of municipal landfill leachate by a combined process. Process Saf. Environ. 2009, 87, 191-196.

2. Torretta, V. PAHs in wastewater: Removal efficiency in a conventional wastewater treatment plant and comparison with model predictions. Environ. Technol. 2012, 33, 851-855.

3. Torretta, V.; Katsoyiannis, A. Occurrence of polycyclic aromatic hydrocarbons in sludges from different stages of a wastewater treatment plant in Italy. Environ. Technol. 2013, 34, 937-943.

4. Luciano, A.; Viotti, P.; Mancini, G.; Torretta, V. An integrated wastewater treatment system using a BAS reactor with biomass attached to tubular supports. J. Environ. Manage. 2012, 113, 51-60.

5. Van Dongen, U.; Jetten, M.S.M.; van Loosdrecht, M.C.M. The SHARON ANAMMOX process for treatment of ammonium rich wastewater. Water Sci. Technol. 2001, 44, 153-160.

6. Notenboom, G.J.; Jacobs, J.C.; van Kempen, R.; van Loosdrecht, M.C.M. High Rate Treatment with SHARON Process of Waste Water from Solid Waste Digestion. In Proceedings of the IWA 3rd International Symposium Anaerobic Digestion of Solid Wastes, Munich, Germany, 11-13 September 2002.

7. Sliekers, A.O.; Third, K.A.; Abma, W.; Kuenen, J.G.; Jetten, M.S.M. CANON and ANAMMOX in a gas lift reactor. FEMS Microbiol. Lett. 2003, 218, 339-344.

8. Khin, T.; Annachhatre, A.P. Novel microbial nitrogen removal processes. Biotechnol. Adv. 2004, 22, 519-532.

9. Van Kempen, R.; ten Have, C.C.R.; Meijer, S.C.F.; Mulder, J.W.; Duin, J.O.J.; Uijterlinde, C.A.; van Loosdrecht, M.C.M. SHARON process evaluated for improved wastewater treatment plant nitrogen effluent quality. Water Sci. Technol. 2005, 52, 55-62. 
10. Mulder, J.W.; Duin, J.O.J.; Goverde, J.; Poiesz, W.G.; van Veldhuizen, H.M.; van Kempen, R.; Roeleveld, P. Full-Scale Experience with the SHARON Process Through the Eyes of the Operators. In Proceedings of the WEFTEC 06, Dallas, TX, USA, 21-25 October 2006.

11. Mulder, A.; van de Graaf, A.A.; Robertson, L.A.; Kuenen, J.G. Anaerobic ammonium oxidation discovered in a denitrifying fluidized bed reactor. FEMS Microbiol. Ecol. 1995, 16, 177-184.

12. Moraes, B.P.; Bertazzoli, R. Electrodegradation of landfill leachate in a flow electrochemical reactor. Chemosphere 2005, 58, 41-46.

13. Martinez-Hiutle, C.A.; Ferro, S. Electrochemical oxidation of organic pollutants for the wastewater treatment: Direct and indirect processes. Chem. Soc. Rev. 2006, 35, 1324-1340.

14. Lei, Y.; Shen, Z.; Huang, R.; Wang, W. Treatment of landfill leachate by combined aged-refuse bioreactor and electro-oxidation. Water Res. 2007, 41, 2417-2426.

15. Istrate, I.A.; Grigoriu, M.; Badea, A.; Rada, E.C.; Ragazzi, M.; Andreottola, G. The Assessment of Chemical and Electrochemical Treatment for the Remediation of Diesel Contaminated Soils. In Proceedings of the Recent Advanges in Risk Management, Assessment and Mitigation, Bucharest, Romania, 8-11 November 2010; pp. 144-149.

16. Oprea, I.; Badea, A.; Ziglio, G.; Ragazzi, M.; Andreottola, G.; Ferrarese, E.; Apostol, T. The remediation of contaminated sediments by chemical oxidation. Sci. Bull. 2009, 71, 131-142.

17. Bashir, M.J.K.; Isa, M.H.; Kutty, S.R.M.; Awang, Z.B.; Aziz, H.A.; Mohajeri, S.; Farooqi, I.H. Landfill leachate treatment by electrochemical oxidation. Waste Manage. 2009, 29, 2534-2541.

18. Bashir, M.J.K.; Aziz, H.A.; Aziz, S.Q.; Amr, S.S.A. An overview of electro-oxidation processes performance in stabilized landfill leachate treatment. Desalin. Water Treat. 2013, 51, 2170-2184.

19. Zhao, X.; Qu, J.; Liu, H.; Wang, C.; Xiao, S.; Liu, R.; Liu, P.; Lan, H.; Hu, C. Photoelectrochemical treatment of landfill leachate in a continuous flow reactor. Bioresource Technol. 2010, 101, 865-869.

20. Kurniawan, T.A.; Lo, W.; Chan, G.Y.S. Radicals-catalyzed oxidation reactions for degradation of recalcitrant compounds from landfill Leachate. Chem. Eng. J. 2006, 125, 35-57.

21. Deng, Y.; Englehardt, J.D. Electrochemical oxidation for landfill leachate treatment. Waste Manage. 2007, 27, 380-388.

22. Primo, O.; Rivero, M.J.; Urtiaga, A.M.; Ortiz, I. Nitrate removal from electro-oxidized landfill leachate by ion exchange. J. Hazard. Mater. 2009, 164, 389-393.

23. Uygur, A.; Kargi, F. Advanced treatment of landfill leachate by a new combination process in a full-scale plant. J. Hazard. Mater. 2009, 172, 408-415.

24. Do, J.S.; Yeh, W.C. Paired electro-oxidative degradation of phenols with in situ generated hydrogen peroxide and hypochlorite. J. Appl. Electrochem. 1996, 26, 673-678.

25. Robinson, H.D.; Knox, K.; Bone, B.D.; Picken, A. Leachate quality from landiflled MBT waste. Waste Manage. 2005, 25, 383-391.

26. Deng, Y.; Englehardt, J.D. Hydrogen peroxide-enhanced iron-mediated aeration for the treatment of mature landfill leachate. J. Hazard. Mater. 2008, 153, 293-299.

27. Li, X.Z.; Zhao, Q.L.; Hao, X.D. Ammonium removal from landfill leachate by chemical precipitation. Waste Manage. 1999, 19, 409-415.

28. Szpyrkowicz, L.; Kaul, S.N.; Neti, R.N.; Satyanarayan, S. Influence of anode material on electrochemical oxidation for the treatment of tannery wastewater. Water Res. 2005, 39, 1601-1613. 
29. Cabeza, A.; Urtiaga, A.M.; Ortiz, I. Electrochemical treatment of landfill leachates using a boron-doped diamond anode. Ind. Eng. Chem. Res. 2007, 46, 1439-1446.

30. Mohan, N.; Balasubramanian, N.; Basha, C.A. Electrochemical oxidation of textile wastewater and its reuse. J. Hazard. Mater. 2007, 147, 644-651.

31. Lin, S.H.; Chang, C.C. Treatment of landfill leachate by combined electro-Fenton oxidation and sequencing batch reactor method. Water Res. 2000, 34, 4243-4249.

32. Zhang, H.; Zhang, D.; Zhou, J. Removal of COD from landfill leachate by electro- Fenton method. J. Hazard. Mater. 2006, 135, 106-111.

33. Atmaca, E. Treatment of landfill leachate by using electro-Fenton method. J. Hazard. Mater. 2009, 163, 109-114.

34. Mohajeri, S.; Aziz, H.A.; Isa, M.H.; Zahed, M.A.; Adlan, M.N. Statistical optimization of process parameters for landfill leachate treatment using electro-Fenton technique. J. Hazard. Mater. 2010, 176, 749-758.

35. U.S. Environmental Protection Agency. Toxicological Review of Hexavalent Chromium; U.S. Environmental Protection Agency: Washington, DC, USA, 1998.

36. Rusănescu, C.O.; Rusănescu, M. The stress-strain curves determined for microalloy steel with V determined on the torsion tests. Metalurgia (Bucharest) 2007, 59, 38-44.

37. Kulikowska, D.; Klimiuk, E. The effect of landfill age on municipal leachate composition. Bioresource Technol. 2008, 99, 5981-5985.

38. Zhang, Q.-Q.; Tian, B.-H.; Zhang, X.; Ghulam, A.; Fang, C.-R.; He, R. Investigation on characteristics of leachate and concentrated leachate in three landfill leachate treatment plants. Waste Manage. 2013. Available online: http://dx.doi.org/10.1016/j.wasman.2013.07.021 (accessed on 22 July 2013).

39. Frascari, D.; Bronzini, F.; Giordano, G.; Tedioli, G.; Nocentini, M. Long-term characterization, lagoon treatment and migration potential of landfill leachate: A case study in an active Italian landfill. Chemosphere 2004, 54, 335-343.

40. U.S. AEC. In-Situ Electrokinetic Remediation of Metal Contaminated Soils-Technology Status Report; Report No. SFIM-AEC-ET-CR-99022; U.S. Army Environmental Center: Fort Sam Houston, TX, USA, 2000.

41. Panizza, M.; Martinez-Huitle, C.A. Role of electrode materials for the anodic oxidation of a real landfill leachate-Comparison between $\mathrm{Ti}-\mathrm{Ru}-\mathrm{Sn}$ ternary oxide, $\mathrm{PbO} 2$ and boron-doped diamond anode. Chemosphere 2013, 90, 1455-1460.

42. Italian Government. Italian Legislative Decree No. 152/2006-Environmental norms. Available online: http://www.camera.it/parlam/leggi/deleghe/06152dl.htm (accessed on 22 July 2013).

43. Stam, A.F.; Meij, R.; Winkel, H.T.; van Eijk, R.J.; Huggins, F.E.; Brem, G. Chromium speciation in coal and biomass co-combustion products. Environ. Sci. Technol. 2011, 45, 2450-2456.

44. Fendorf, S.E. Surface reactions of chromium in soils and water. Geoderma 1995, 67, 55-71.

45. Di Mauro, C.; Bouchon, S.; Torretta, V. Industrial risk in the Lombardy Region (Italy): What people perceive and what are the gaps to improve the risk communication and the partecipatory processes. Chem. Eng. Trans. 2012, 26, 297-302.

46. Ilhan, F.; Kurt, U.; Apaydin, O.; Gonullu, M.T. Treatment of leachate by electrocoagulation using aluminum and iron electrodes. J. Hazard. Mater. 2008, 154, 381-389. 
47. Alvarez-Guerra, E.; Dominguez-Ramos, A.; Irabien, A. Design of the Photovoltaic Solar Electro-Oxidation (PSEO) process for wastewater treatment. Chem. Eng. Res. Des. 2011, 89, 2679-2685.

48. Alvarez-Guerra, E.; Dominguez-Ramos, A.; Irabien, A. Photovoltaic solar electro-oxidation (PSEO) process for wastewater treatment. Chem. Eng. J. 2011, 170, 7-13.

49. Dominguez-Ramos, A.; Aldaco, R.; Irabien, A. Photovoltaic solar electrochemical oxidation (PSEO) for treatment of lignosulfonate wastewater. J. Chem. Technol. Biot. 2010, 85, 821-830.

50. Valero, D.; Ortiz, J.M.; Expósito, E.; Montiel, V.; Aldaz, A. Electrochemical wastewater treatment directly powered by photovoltaic panels: Electro-oxidation of a dye-containing wastewater. Environ. Sci. Technol. 2010, 44, 5182-5188.

(C) 2013 by the authors; licensee MDPI, Basel, Switzerland. This article is an open access article distributed under the terms and conditions of the Creative Commons Attribution license (http://creativecommons.org/licenses/by/3.0/). 